\title{
Generation of a global fuel data set using the Fuel Characteristic Classification System
}

\author{
M. Lucrecia Pettinari and Emilio Chuvieco \\ Department of Geology, Geography and Environment, University of Alcala, Alcalá de Henares, 28801, Spain \\ Correspondence to: M. Lucrecia Pettinari (mlucrecia.pettinari@uah.es)
}

Received: 27 September 2015 - Published in Biogeosciences Discuss.: 27 October 2015

Revised: 19 February 2016 - Accepted: 16 March 2016 - Published: 8 April 2016

\begin{abstract}
This study presents the methods for the generation of the first global fuel data set, containing all the parameters required to be input in the Fuel Characteristic Classification System (FCCS). The data set was developed from different spatial variables, both based on satellite Earth observation products and fuel databases, and is comprised by a global fuelbed map and a database that includes the parameters of each fuelbed that affect fire behavior and effects. A total of 274 fuelbeds were created and parameterized, and can be input into FCCS to obtain fire potentials, surface fire behavior and carbon biomass for each fuelbed.

We present a first assessment of the fuel data set by comparing the carbon biomass obtained from our FCCS fuelbeds with the average biome values of four other regional or global biomass products. The results showed a good agreement both in terms of geographical distribution and biomass loads when compared to other biomass data, with the best results found for tropical and boreal forests (Spearman's coefficient of 0.79 and 0.77).

This global fuel data set may be used for a varied range of applications, including fire danger assessment, fire behavior estimations, fuel consumption calculations and emissions inventories.
\end{abstract}

\section{Introduction}

Fire is an important process in the Earth system, with a global burned area of 3.0-3.8 million $\mathrm{km}^{2}$ (Giglio et al., 2013; Alonso-Canas and Chuvieco, 2015), and multiple biophysical, ecological, and socioeconomic consequences. It has shaped the Earth's vegetation through its history, altering vegetation composition by preventing the growth of some plant types while promoting others, thus creating flammable ecosystems where other vegetation would exist based solely on climate or soil (Pausas and Keeley, 2009). Fire is also an important source of atmospheric gases and aerosol particles, including gasses such as $\mathrm{CO}_{2}, \mathrm{CO}$, and $\mathrm{CH}_{4}$ (Schultz et al., 2008).

The characteristics of the vegetation and the environmental conditions affecting the fuels are considered the primary factors in fire initiation, behavior, and effects (Rothermel, 1983). Variables such as fuel loading, fuel depth, stand structure, fuel moisture, etc., will determine fire behavior parameters such as rate of spread, fire intensity, or fuel consumption, amongst others (Cohen and Deeming, 1985). Fuel variables are commonly grouped in fuel types, following different classification systems. Fuel types are frequently created to account for the vegetation characteristics of a particular region, such as the case of the fuels created for Southeast Asia (Dymond et al., 2004), or for the Mediterranean ecosystems (PROMETHEUS S.V. Project, 1999; Riaño et al., 2002). When fuel types are used as input to fire behavior models they are converted to fuel models, which include the specific parameters necessary to run fire simulation programs. Such is the case of the 13 fuel models of the Northern Forest Fire Laboratory (NFFL) (Rothermel, 1972), the 20 fuel models of the National Fire Danger Rating System (NFDRS) (Cohen and Deeming, 1985), or the 17 fuel types of the Canadian Fire Behavior Prediction System (FBP) (Stocks et al., 1989). Other fuel type classifications were created with a broader scope. The Fuel Characteristic Classification System (FCCS) (Ottmar et al., 2007), for example, uses the concept of fuelbed to represent a relatively homogeneous unit in the landscape with a distinct combustion environment (Riccardi et al., 2007), and includes information on physical and bio- 
logical variables that allow for both fire behavior (through an adaptation of the Rothermels' equations) and effects (emissions) calculations, which can be used for fuel management at different scales (McKenzie et al., 2007).

Maps including information on fuel types are a necessary input for fire risk and fire effects assessment. At local or regional scale, fuel maps are useful for spatial modeling of fire risk assessment (Finney et al., 2011; Chuvieco et al., 2014) and real-time analysis of fire behavior (Dymond et al., 2004; McKenzie et al., 2007). Continental or global fuel maps, meanwhile, are usually used for carbon-cycle or air-quality modeling (Keane et al., 2001; McKenzie et al., 2007; San Miguel-Ayanz et al., 2012), and they can also be used for the estimation of continental to global fire danger (SebastiánLopez et al., 2001; Pettinari et al., 2014).

Different approaches can be used to create fuel maps. Field surveys have been used to provide detailed information on fuel characteristics, but they are costly to implement, and thus are only useful for small areas (Keane et al., 2001; Rollins et al., 2004; McKenzie et al., 2007). Ecological modeling employs environmental gradients such as climate and topography, as well as ecosystem dynamic models, to create vegetation and fuel maps (Keane et al., 2001; Rollins et al., 2004). Remote-sensing approaches are sound alternatives to fuel type mapping, as they provide updated spatial coverage and are sensitive to some of the critical variables for fuel type definition: fuel loads, horizontal and vertical continuity, fuel moisture, etc., particularly when using lidar observations (Riaño et al., 2004).

Previous fuel maps created at continental scales have relied on the use of remote-sensing information, usually reclassified to land cover classes, and ancillary data from other sources, such as potential vegetation, canopy cover, etc. Some examples of continental or sub-continental fuel maps are the National Fuel-type map for Canada (Nadeau et al., 2005), the LANDFIRE fuel maps for the United States, which include several fuel type classifications (http://www. landfire.gov/, last access: January 2016) and the European fuel map used by the European Forest Fire Information System (EFFIS) (San Miguel-Ayanz et al., 2012).

The objective of this paper is presenting the methods to generate a global fuel map based on the FCCS approach. Our goal was to deliver a global product to the international community interested in improving the modeling of fire danger and fire effects assessment. To our knowledge, global fuel maps are not yet available, thus this paper is a first attempt to generate a planetary fuel data set that is based on consistent inputs. In addition, since the FCCS is the base for the fuel typology, quantitative estimations of fire risk and behavior parameters can be generated from the final product. In a previous study, we created a fuel map for South America using the FCCS methodology (Pettinari et al., 2014). In this study, we have extended that methodology to create a global fuel data set using FCCS, which required the inclusion of new sources of data to reflect the characteristics of biomes and ecosystems not present in South America. Also, the methodology was expanded, adding more spatial variability to the fuelbeds and updating some sources of information, amongst other improvements. In addition, we have undertaken a first assessment of our product by comparing the biomass estimations provided by the FCCS outputs of our fuelbeds with existing regional or global biomass products.

\section{Methods}

The development of the global fuelbed data set is based on the Fuel Characteristic Classification System (FCCS), which is both a conceptual framework and a software tool for quantifying fuels (Ottmar et al., 2007). The fuel characteristics are organized into six strata including trees, shrubs, grasses, woody surface fuels, litter and soil organic matter (duff), and are referred to as fuelbeds. We have used version 3.0 of the FCCS software, which is integrated into the Fuel and Fire Tools (FFT, available at http://www.fs.fed.us/pnw/ fera/fft/index.shtml, last access: September 2015). FFT is a software application that integrates different fire characteristics, behavior, and effects tools developed by the Fire and Environmental Research Applications Team (FERA) of the United States Forest Service (USFS).

FCCS was selected to develop the fuel data set because it has the advantage that it includes a wide set of physical characteristics of the fuels, and not only the ones required by a particular fire model such as NFFL or NFDRS. The NFFL models were developed for uniform continuous fuels and for the severe period of the fire season (Anderson, 1982; Rothermel, 1983), and they do not describe fuels with higher live fuel moisture or that burn well at high humidity (Scott and Burgan, 2005). FCCS, meanwhile, allows creating fuelbeds for environments not contemplated by other models, such as moist ecosystems that are found in several parts of the world. Also, the parameters included in the FCCS fuelbeds also provide information on the crown and ground fuels, not included in most models only developed for surface fuels (Cohen and Deeming, 1985; Scott and Burgan, 2005). This extends its use to other applications beyond fire behavior estimations, allowing also estimating crown fire potentials, the amount of available fuel or predicting fuel consumption.

The fuelbeds to create our global fuel type data set were developed in two stages: first land cover products and a biome map were used to identify fuelbed categories, along with their geographic location, creating a fuelbed map. Then, each fuelbed was given a set of parameters that determine their fire behavior and effects. The fuelbed parameters can be input in the FCCS software, and the results can be mapped joining the results to the fuelbed map (Fig. 1). An example is given on estimated biomass, which is compared with external data bases. 


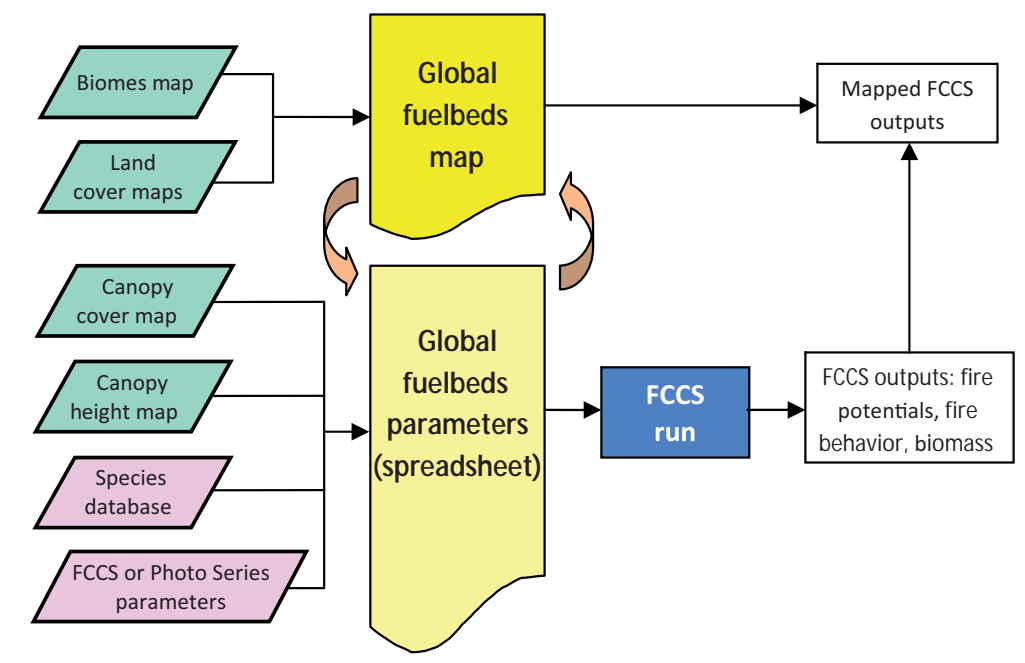

Figure 1. General flowchart of the methodology used for the generation of the global fuel data set. More detailed steps are shown in Figs. 2 and 3 .

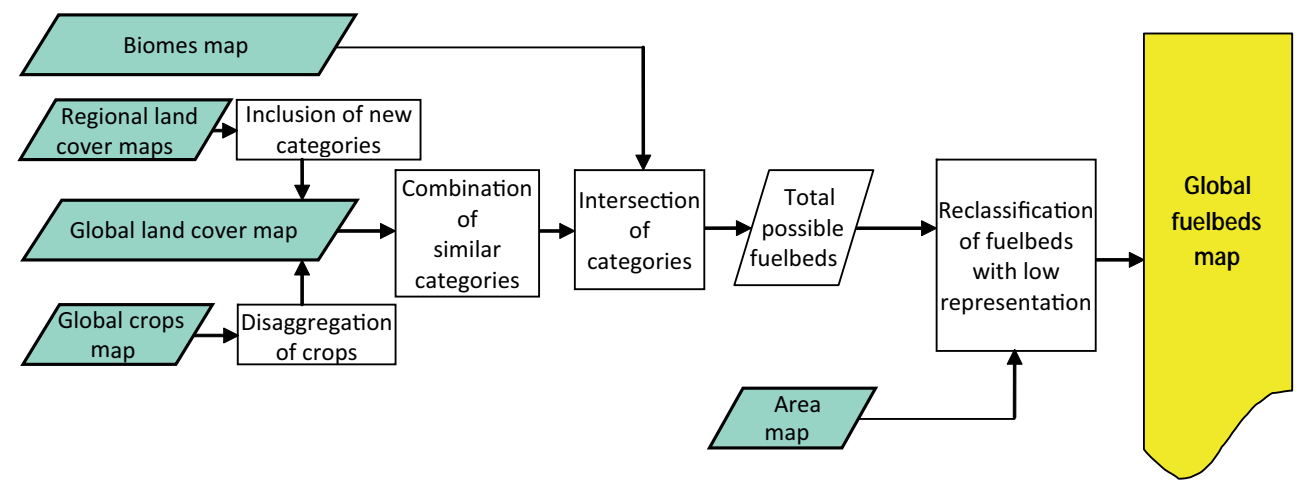

Figure 2. Flow chart of the steps performed for the generation of the fuelbeds.

\subsection{Generation of the fuelbeds}

The first stage of the development of the fuel map comprises the delineation of the fuelbeds, and the creation of the map itself. A flow chart summarizing the steps to obtain the fuelbeds is included in Fig. 2.

The land cover information was extracted primarily from the GlobCover 2005 V2.2 product (Bicheron et al., 2008), developed from a temporal series of MERIS (MediumResolution Imaging Spectrometer) images acquired between December 2004 and June 2006. This product has a spatial resolution of $10 \operatorname{arcsec}(\sim 300 \mathrm{~m}$ at the Equator $)$ and its legend was defined using the Land-cover Classification System (LCCS) of the United Nations' Food and Agricultural Organization (Di Gregorio, 2005). The GlobCover V2.2 has both global and regional maps. The global map uses the Level 1 of LCCS, which consists of 22 classes, 18 of which include vegetation. In addition to the global GlobCover 2005 product, other land cover products were used to solve some problems or limitations that we found in this map. For instance, the Global GlobCover product did not include a specific class for needle-leaved deciduous forests (ND), which was mixed with the needle-leaved evergreen (NE) forests. Since both categories have distinct fire behavior, the regional GlobCover V2.2 maps (Bicheron et al., 2008) corresponding to Eastern Europe and Central Asia were used, as they discriminate between NE and ND. For our map, the pixels from the global map were reclassified into those two categories following the regional GlobCover maps classification.

Another important adaptation of the global land cover map was linked to the Australian eucalyptus class, which was included in the standard GlobCover with the broadleaved evergreen or semi-deciduous (BE) forests. However, it is well known that Eucalyptus sp. is much more flammable than other major broadleaved evergreen species due to their high concentration of volatile compounds (Kesselmeier and Staudt, 1999) and the production and accumulation of large amounts of flammable litter from the leaves and bark (Agee et al., 1973). Since these species are one of the primary tree species in the Australian continent, specific fuelbeds 


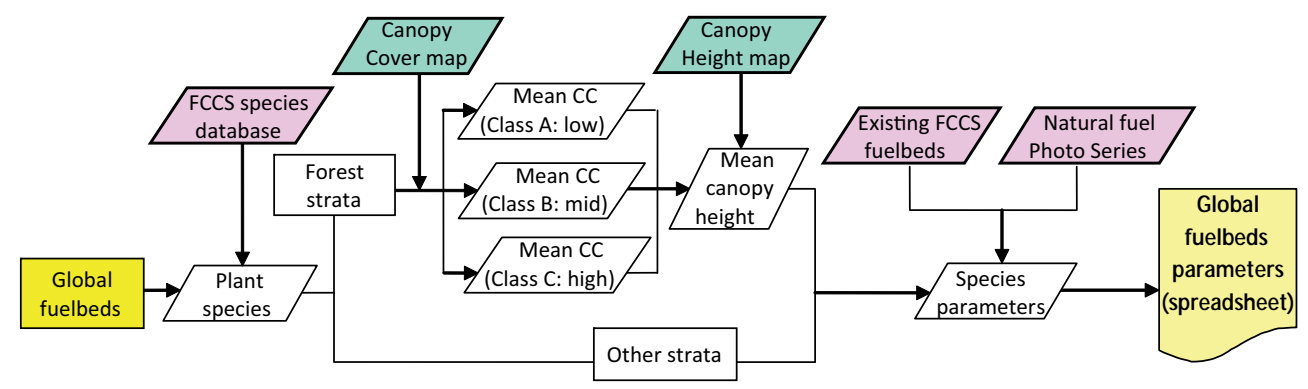

Figure 3. Flow chart of the steps performed for the parameterization of the fuelbeds. CC: canopy cover.

were created for that region. The GlobCover product assigned vast regions of Australia as broadleaved deciduous (BD) forests, which was in disagreement with other sources of Australian vegetation information (Department of the Environment and Water Resources, 2007). In order to account for this, the map of major vegetation groups in Australia V3.0 (http://www.environment.gov.au/resource/ major-vegetation-groups-australia\#map, last access: January 2016) was used to reclassify the pixels from BD to BE (mainly eucalyptus and acacias) when the Australian map showed a majority of this type of vegetation. A new land cover class was created to represent this type of vegetation.

Regarding the crops, even though the GlobCover V2.2 product only distinguishes between rainfed and irrigated croplands, fuel conditions and biomass are very different in some of the most extended crops. To assign individual crops species to the cropland classes the "Harvested Area and Yield of 175 crops" map was used (http://www.earthstat. org/data-download/, last access: January 2016). This map shows the global distribution of 175 different crops according to crop areas, yields, physiological types, and primary production in the year 2000, based on satellite data sets and national and regional agricultural statistics (Monfreda et al., 2008). Only the 15 crops with the highest global harvested area were considered, and these data were extracted from the FAOSTAT's crops production database (Food and Agriculture Organization of the United Nations, Statistics Division, http://faostat3.fao.org/faostat-gateway/go/to/ download/Q/QC/E, last access: January 2016). The land cover classes that include croplands were subdivided according to the world countries' first order administrative divisions (extracted from the ESRI World Administrative Division Map, http://www.arcgis.com/home/item.html?id= d86e32ea12a64727b9e94d6f820123a2, last access: January 2016). For each land cover and administrative division, the crop with the highest harvested area from the 15 crops considered was identified, and assigned to that land cover class and region. For the countries with no information in the crop's map, the crop was assigned based on the FAOSTAT statistics.

Once the global land cover classes were complemented with the ancillary information, some of the classes were com- bined. Both rainfed and irrigated were grouped when they corresponded to the same crop, because they did not represent a difference in vegetation characteristics for the objective of the fuelbed classification. Also, the classes that differed only in their vegetation density (close or open) were merged.

The biomes description was extracted from the Map of Terrestrial Ecoregions (Olson et al., 2001), as it is widely used by different international organizations, including the World Wildlife Fund (WWF). The description includes 14 global vegetated biomes and more than 800 ecoregions. In order to decrease the total number of fuelbeds, we considered that it was possible to eliminate biomes 9 (Flooded Grasslands and Shrublands) and 10 (Montane Grasslands and Shrublands), as they shared many vegetation characteristics with other fuelbeds in nearby biomes. The different patches of these two biomes were reclassified to the biomes that limited with them. As a result, a total of 12 vegetated biomes were considered for the combination with the land cover classes.

The intersection of the land cover classes and the biomes was performed at the spatial resolution of the land cover map. An area map was developed to represent the area of each 10 arcsec pixel of the GlobCover map, and it was used to calculate the total area of each possible combination of land cover class and biome. The combinations with low representation $\left(<0.01 \%\right.$ of global land area: $\left.14900 \mathrm{~km}^{2}\right)$ were reclassified into other similar categories. With this step, the final fuelbed map was generated, with the delineation and the geographic location of the global fuelbeds.

\subsection{Parameterization of the fuelbeds}

Once the spatial distribution of the fuelbeds was defined, a set of parameters that affect fire behavior and effects was assigned to each fuel stratum (tree, shrubs, grasses, woody surface fuels, litter, and ground fuels). These parameters are listed in Table 1. A flow chart of the steps followed is shown in Fig. 3.

Percentage cover of trees was extracted from the MODIS vegetation continuous field (VCF), Collection 5 (DiMiceli et al., 2011) corresponding to the year 2005, to be coetaneous 
Table 1. Parameters assigned to each fuelbed.

\begin{tabular}{|c|c|}
\hline Stratum (and categories) & Parameter \\
\hline Canopy (primary and secondary layers) & $\begin{array}{l}\text { Percent cover }{ }^{\mathrm{a}} \text {, height }{ }^{\mathrm{a}} \text {, height to live crown (HLC), tree density, diameter at } \\
\text { base height }(\mathrm{DBH}) \text {, existence of ladder fuels, tree species, and relative cover }\end{array}$ \\
\hline Shrub (primary layer) & Percent cover, height, percent live, shrub species, and relative cover ${ }^{b}$ \\
\hline Herb (primary layer) & Percent cover, height, percent live, load, herb species, and relative cover ${ }^{b}$ \\
\hline Woody fuels (sound woody) & Percent cover, depth, fuel load by size class $(1,10,100,1000 \mathrm{~h})$ \\
\hline Litter, lichen, and moss & Percent cover, depth, litter arrangement, and percent relative cover by type, moss type \\
\hline Ground fuels (upper and lower duff) & Percent cover, depth, type \\
\hline
\end{tabular}

with the base land cover product. This product has a spatial resolution of $250 \mathrm{~m}$ (Carroll et al., 2011) and describes the percent of a pixel which is covered by tree canopy $(>5 \mathrm{~m}$ high). The map was resampled to the land cover spatial resolution. In order to include more variability in canopy cover (CC) than in previous studies (Pettinari et al., 2014), the percentage of CC was subdivided into three classes: $0-40 \%$ (named class A), 40-70\% (class B) and 70-90\% (class C) as shown in Fig. 4. The value of $40 \%$ was assigned because that is the threshold used in FCCS to decide if canopy fire spread can occur (Prichard et al., 2013). The $70 \%$ threshold was assigned to divide the rest of the existing canopy percentage in two equal parts. No valid values above $90 \%$ appeared in the resampled map. The area of each fuelbed corresponding to each CC class was calculated. If a fuelbed included two or three CC classes with an area higher than $0.01 \%$ of global land area, it was subdivided into as many sub-fuelbeds as complied with the minimum area criterion. Otherwise, it remained as a single fuelbed. After this step, the canopy cover mean value was calculated for each fuelbed or sub-fuelbed, and assigned to it.

Canopy height was extracted from the global canopy height map developed by Simard et al. (2011), which was created using lidar data and ancillary data corresponding to slope, climate and vegetation characteristics. The lidar data was acquired in 2005 by the Geoscience Laser Altimeter System (GLAS) on board the ICESat mission (http://nsidc.org/ data/GLAH14, last access: January 2016). The canopy height database had a spatial resolution of $1 \mathrm{~km}$, and was resampled to the land cover map resolution using nearest neighbor interpolation. As in the case of the canopy cover, the mean value of the canopy height was calculated for each fuelbed or subfuelbed, and assigned as one of the required parameters of the fuelbeds.

To assign the main species of trees, shrubs, and grasses to each fuelbed, the representative plant species for each biome were extracted from the description of the Terrestrial Ecoregions of the World Wildlife Fund (WWF) (http://www.

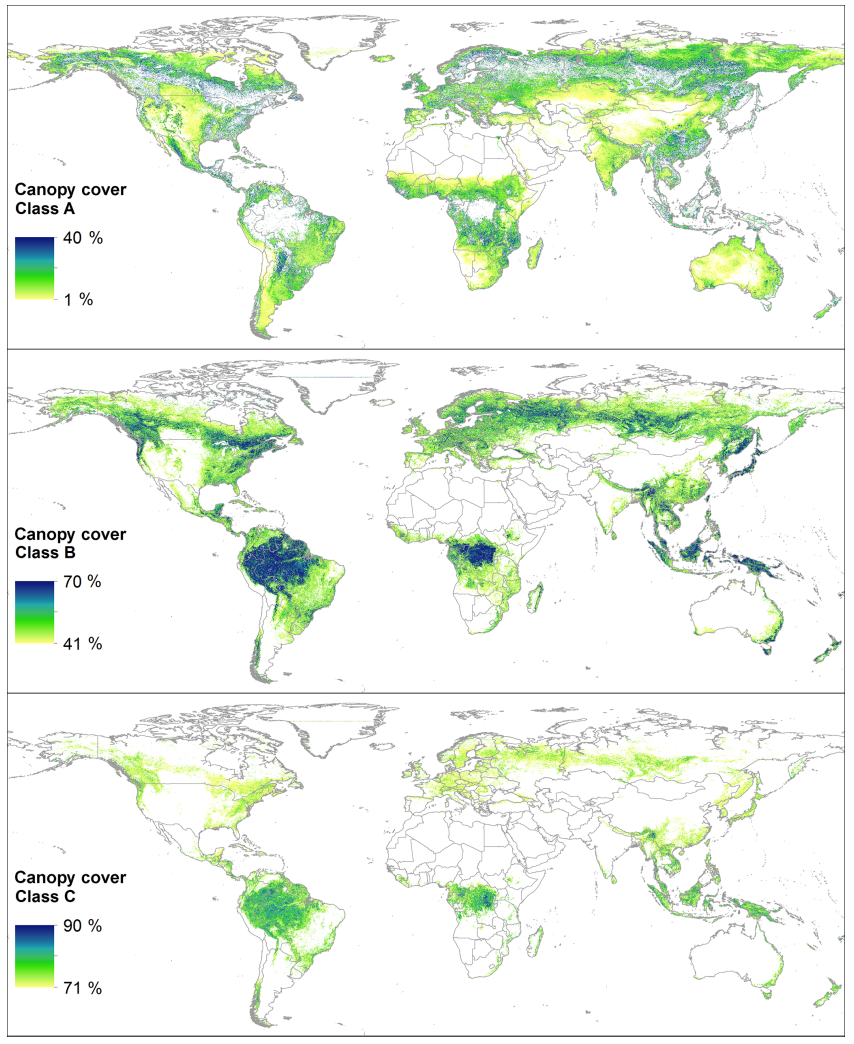

Figure 4. Percentage canopy cover, derived from the MODIS VCF Collection 5 product. The maps show the subdivision of the $\mathrm{CC}$ into the three classes considered for classification.

worldwildlife.org/biome-categories/terrestrial-ecoregions, last access: January 2016). One or two representative species of each type of vegetation were assigned to each individual fuelbed from the list available within FCCS, considering the vegetation form and foliage type most characteristic within every fuelbed. In the case of the crop fuelbeds, the 15 crops considered were grouped to 10 categories, according to their characteristics, and they were assigned the most similar 
agricultural fuelbed from the ones developed by French et al. (2013).

The remaining variables for each fuelbed (Table 1) were assigned based on information from existing fuelbeds in the FCCS database or from the Natural Fuels Photo Series from Mexico (Morfín-Ríos et al., 2008) and Brazil (Ottmar et al., 2001). The existing FCCS database, which includes fuelbeds in most biomes, from the Alaskan Tundra to the tropical forests of Florida and Hawaii, was used if possible, because its fuelbeds have all the necessary parameters required to calculate the fire potentials. For each global fuelbed, the existing similar FCCS fuelbeds were selected based on the biome in which they appear and their vegetation form, foliage type, and plant species, and the mean values of their parameters were used to populate the global fuelbed variables, with some adjustments in the tree layer if necessary due to the differences in canopy cover and/or height. The Natural Fuels Photo Series were used primarily for the tropical fuelbeds because they most accurately represent the vegetation found in those biomes. Some variables were assigned based on expert opinion whenever there was no other information available.

\subsection{Fuel map assessment}

Strict validation of our product was not feasible as it would imply a huge groundwork effort, particularly to obtain average fuel parameters. Comparison with other fuel products was also problematic, as regional fuel types use many different classification systems (Rollins, 2009; San Miguel-Ayanz et al., 2012). For these reasons, as a first assessment of the fuelbed data set we decided to compare estimations produced by FCCS with existing databases. We selected the carbon biomass, since this variable has been modeled at global and regional scales by different research groups.

FCCS estimates the amount of total biomass and carbon load per stratum based on the parameters assigned to each strata and a set of biomass equations for different types of vegetation (Prichard et al., 2013). This biomass is used for the calculation of the available fuel potential and biomass consumption in the Consume Module inside FFT (http: //www.fs.fed.us/pnw/fera/fft/consumemodule.shtml, last access: January 2016). For our product, once the biomass values were computed at the raw resolution of the database ( $\sim 9$ ha $)$, they were aggregated into $0.5^{\circ} \times 0.5^{\circ}$ cells. Cells with homogeneous land cover types ( $>80 \%$ of the cell) were selected for the comparison exercise. The following biomass products were compared with our estimations:

- Global biomass from the Orchidee Dynamic Global Vegetation Model (DGVM) (Krinner et al., 2005), as estimated from Yue et al. (2015). The biomass was obtained from a vegetation distribution map classified into 13 plant functional types based on the IGBP vegetation map (Loveland et al., 2000).
- Northern boreal and temperate above-ground biomass (AGB) from the carbon stock and density map developed by Thurner et al. (2014). This map is based on the growing stock volume (GSV) estimates obtained with the Biomasar algorithm (Santoro et al., 2011) using ENVISAT ASAR images.

- Tropical biomass from the above-ground live woody vegetation carbon density map developed by Baccini et al. (2012).

- Tropical biomass from the forest carbon stocks map developed by Saatchi et al. (2011).

Both of these tropical biomass data sets (from now on referred to as the Baccini and Saatchi maps) use similar remote-sensing inputs, mainly the lidar data from the ICESat GLAS, but they use different ground-based data sets and modeling methods to extend the GLAS footprints to fullcoverage AGB maps. The differences between the two maps are described in Mitchard et al. (2013).

\section{Results}

\subsection{Global fuelbed map}

The final fuelbed map contains 274 main fuelbeds. As some of them were subdivided considering their canopy cover, the value increased to 359 when the sub-fuelbeds were considered. The resulting fuelbed map is shown in Fig. 5. Each fuelbed is identified by a number where the first two digits correspond to the biome, and the following three identify the land cover type associated with a pixel. For example, fuelbed 13140 is in the Desert and Xeric Shrublands biome (13) and associated with grassland vegetation (140).

The inclusion of the regional GlobCover maps of Eastern Europe and Central Asia resulted in the creation of 30 dedicated ND fuelbeds or sub-fuelbeds in biomes 11 (tundra), 8 (temperate grasslands, savannas, and shrublands), 6 (boreal forest/taiga), 5 (temperate coniferous forests), and 4 (temperate broadleaf and mixed forests). Similarly, $25 \mathrm{fu}-$ elbeds or sub-fuelbeds were created specifically for Australia, in biomes 4, 8, 7 (tropical and subtropical grasslands, savannas, and shrublands), 12 (Mediterranean forests, woodlands, and scrub) and 13 (desert and xeric shrublands). The fuelbed with the largest area is 1040 (broadleaved evergreen or semi-deciduous forest vegetation in a tropical and/or subtropical moist broadleaf forest biome), with 10.4 million $\mathrm{km}^{2}$, which is subdivided in three sub-fuelbeds: $1040 \mathrm{a}$ ( $1-40 \%$ canopy cover) with 1.7 million $\mathrm{km}^{2}, 1040 \mathrm{~b}$ (41-70\% CC) with 2.9 million $\mathrm{km}^{2}$, and $1040 \mathrm{c}(71-90 \%$ CC) with 5.8 million $\mathrm{km}^{2}$. The second largest area, with 4.3 million $\mathrm{km}^{2}$, belongs to both the sparse vegetation in the tundra biome (fuelbed 11150), and the needle-leaved evergreen forest in the boreal forest/taiga biome (fuelbed 


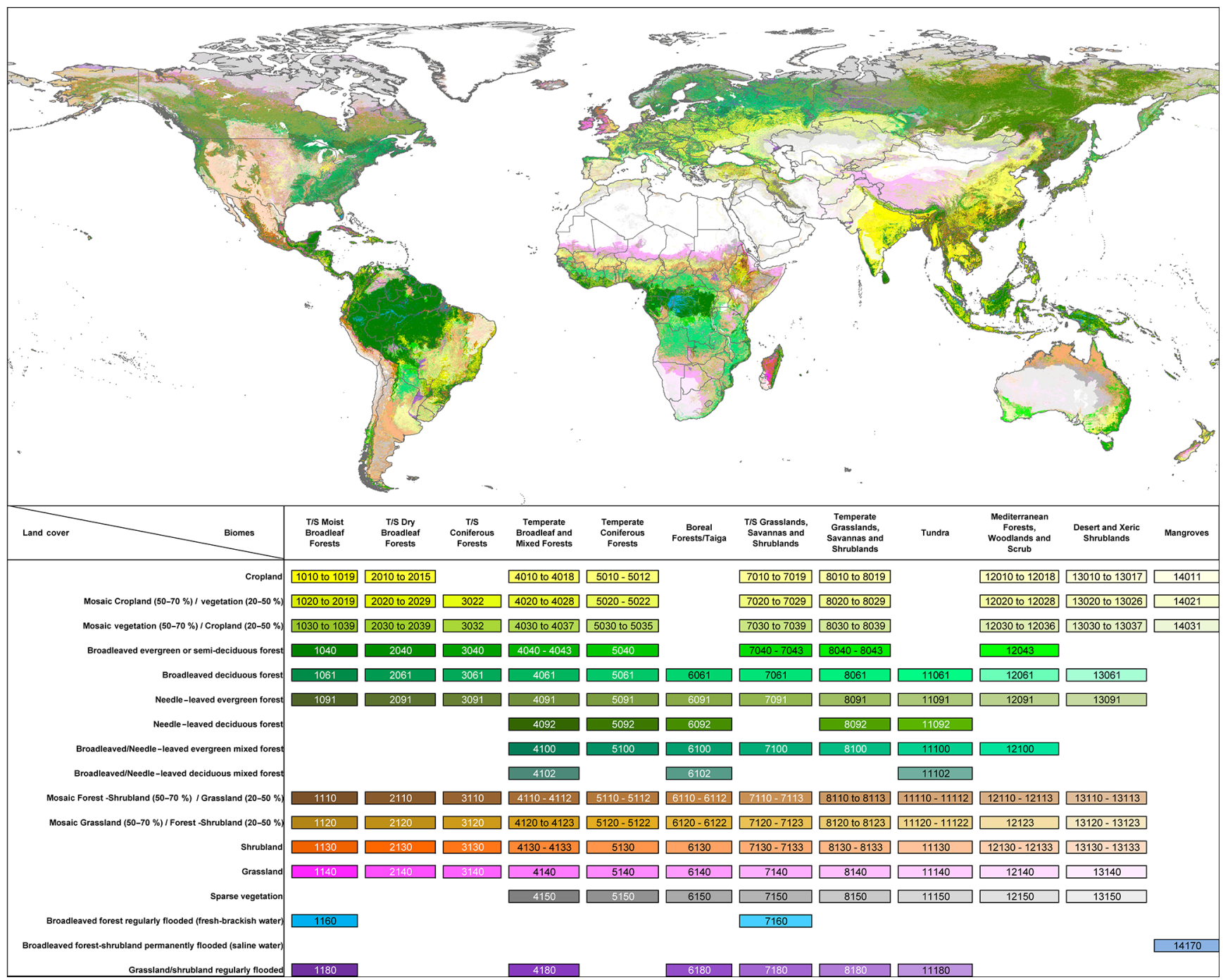

Figure 5. Global fuelbed map. The color legend details the number of the fuelbeds, and the land cover and biome that they represent.

6091), which is subdivided into two sub-fuelbeds: 6091a (1.8 million $\mathrm{km}^{2}$ ) and $6091 \mathrm{~b}\left(2.5\right.$ million $\left.\mathrm{km}^{2}\right)$.

\subsection{Carbon biomass}

Figure 6 shows the FCCS estimations of carbon biomass values computed from our product. There were 11 fuelbeds with biomass higher than $200 \mathrm{MgCha}^{-1}$. All of these fuelbeds represent forests with high canopy cover (sub-fuelbeds b or c). In five of those fuelbeds the main sources of biomass were the trees; these were the sub-fuelbeds $12091 \mathrm{~b}, 5100 \mathrm{c}$, $12061 b$, 4091c, and 4043c, which correspond to temperate and Mediterranean forests. In the remaining six fuelbeds with highest biomass, the main source of carbon biomass was located in the ground fuel stratum, corresponding to the duff. These sub-fuelbeds were located in the mangrove (14170c), in temperate ND (4092b), in boreal (6091c, 6092c, 6102b), and in tundra (11091b) forests.

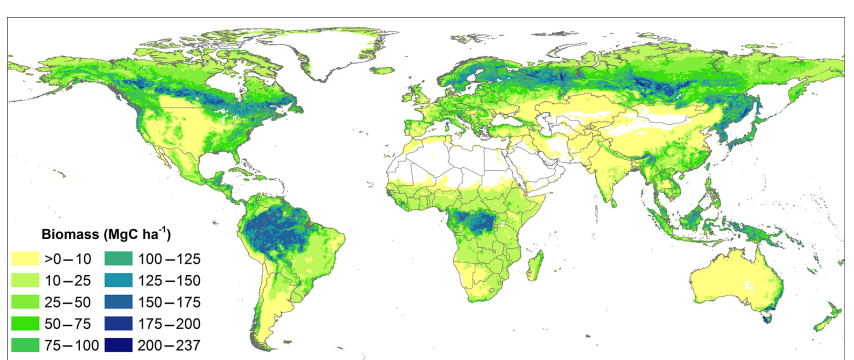

Figure 6. Estimated global carbon biomass obtained from the global fuelbed data set.

The comparison between the biomass results in this study and the other products used for our comparison exercise (also aggregated at $0.5^{\circ} \times 0.5^{\circ}$ resolution) is shown in Table 2 . This table shows mean and standard deviation values for different biomes, as computed from homogeneous land cover cells. It 
Table 2. Carbon biomass obtained as mean values of the 0.5 degree pixels with at least $80 \%$ of the land cover analyzed, in units of $\mathrm{MgCha}^{-1}$. Standard deviation values are shown in parenthesis. The values of the Spearman's rho coefficient compared to the results from this study are shown in brackets*.

\begin{tabular}{|c|c|c|c|c|c|c|}
\hline Land cover & $\begin{array}{l}\text { This study, } \\
\text { total biomass }\end{array}$ & Orchidee $^{a}$ & Baccini $^{b}$ & Saatchi ${ }^{\mathrm{c}}$ & $\begin{array}{l}\text { Biomasar, } \\
\text { AGB }^{\mathrm{d}}\end{array}$ & $\begin{array}{l}\text { This study, } \\
\text { tree biomass only }\end{array}$ \\
\hline Tropical forest & $\begin{array}{l}110.0 \\
(50.3)\end{array}$ & $\begin{array}{c}146.6 \\
(64.1)[0.67]\end{array}$ & $\begin{array}{c}109.1 \\
(46.3)[0.79]\end{array}$ & $\begin{array}{c}99.4 \\
(42.4)[0.59]\end{array}$ & - & - \\
\hline Boreal forest & $\begin{array}{l}107.3 \\
(36.6)\end{array}$ & $\begin{array}{c}28.8 \\
(17.7)[0.27]^{*}\end{array}$ & - & - & $\begin{array}{c}30.9 \\
(13.6)[0.77]^{*}\end{array}$ & $\begin{array}{c}32.4 \\
(19.6)\end{array}$ \\
\hline Temperate forest & $\begin{array}{l}91.8 \\
(25.0)\end{array}$ & $\begin{array}{c}63.2 \\
(39.1)[0.39]^{*}\end{array}$ & - & - & $\begin{array}{c}49.5 \\
(20.4)[0.42]^{*}\end{array}$ & $\begin{array}{l}70.6 \\
(21.3)\end{array}$ \\
\hline Savanna + shrub & $\begin{array}{c}8.1 \\
(5.2)\end{array}$ & $\begin{array}{c}15.5 \\
(18.1)[0.66]\end{array}$ & - & - & - & - \\
\hline Grasses & $\begin{array}{c}3.3 \\
(5.3)\end{array}$ & $\begin{array}{c}4.2 \\
(7.0)[0.20]\end{array}$ & - & - & - & - \\
\hline Crops & $\begin{array}{c}5.2 \\
(4.4)\end{array}$ & $\begin{array}{c}12.3 \\
(14.7)[0.40]\end{array}$ & - & - & - & - \\
\hline
\end{tabular}

References to the data: ${ }^{a}$ Yue et al. (2015), ${ }^{b}$ Baccini et al. (2012), ${ }^{c}$ Saatchi et al. (2011), ${ }^{\mathrm{d}}$ Thurner et al. (2014).

* The coefficients marked with the asterisk are compared to the results from this study, considering tree biomass only. The rest of the values compare the different products with the results of this study considering the total biomass.

also includes the Spearman's rho correlation coefficient between the different products and the results from our study. Figure 7 shows the biomass distribution of the different products in the form of box plots.

The tropical forest carbon biomass shows the highest consistency between our estimations and the external products used for comparison, with a Spearman's coefficient of 0.79 between this study and the Baccini product. Only the Orchidee estimations are clearly above the others (by $40 \%$ ). The box plot distribution (Fig. 7a) also shows a similar biomass distribution amongst the fuelbeds and the Baccini and Saatchi map, with the Orchidee one having the biggest discrepancies.

Regarding the boreal forest fuelbeds, the values obtained in this study for total carbon biomass are 3.5 to 3.7 times higher than the other biomass products, which is easily appreciable in Fig. 7b. As described earlier in this section, in some of the fuelbeds with highest biomass located in boreal, tundra or temperate biomes, a significant proportion of biomass for these regions is stored in the ground fuel stratum. The Biomasar product includes above-ground biomass (AGB) and root biomass, but does not have a duff component. For this reason, the values of carbon biomass corresponding only to the tree stratum of the fuelbeds were used for comparison. In that case, the tree carbon biomass from this study was similar to the Biomasar for the boreal forest (only $5 \%$ lower). The Spearman's coefficient $\left(\rho_{\mathrm{S}}=0.77\right.$ ) also shows a significant correlation between the results obtained for this study and the Biomasar data. Finally, taking into account only the tree biomass of the temperate forests obtained for the fuelbeds, the mean and median values obtained are higher than the values obtained for the Orchidee and Biomasar products (see Table 2 and Fig. 7d). The correlation coefficients are also low to moderate $\left(\rho_{\mathrm{S}}=0.39\right.$ and 0.42 , respectively).

The mean biomass of the grasses fuelbeds is similar to the one obtained from the Orchidee biomass map, but the correlation is poor $\left(\rho_{\mathrm{S}}=0.20\right)$. The box plot in Fig. $7 \mathrm{f}$ shows a significant number of outlier values that could explain this low coefficient. In the case of the savanna and shrub areas, on the other hand, the mean biomass values are much lower for the fuelbeds than for the Orchidee estimations (52\%). The box plot for this land cover (Fig. 7e) shows that the median values are similar for both products (7.04 for this study and 6.23 for the Orchidee map), but the mean value is different due to the much higher positive skew of the Orchidee biomass data. Still, the value obtained for the Spearman's correlation is moderate $\left(\rho_{\mathrm{S}}=0.66\right)$, showing a reasonable association between the values of the two products. Regarding the crops biomass (Fig. 7c), the differences in the skewness and the median values ( 3.76 vs. 8.56 ) between the two distributions are more appreciable. This results in the mean biomass of the Orchidee product being 2.3 times higher than the value obtained for this study.

\section{Discussion}

The fuelbed map developed in this study is the first global product that describes the characteristics of the vegetation related to fire behavior and effects, and should be useful 


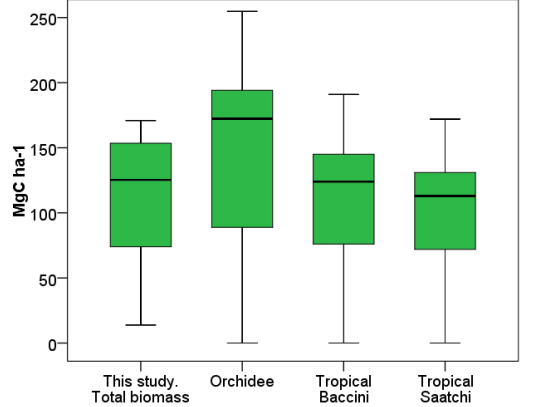

(a)

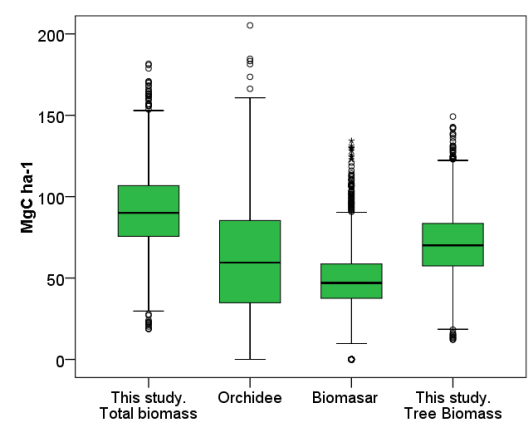

(d)

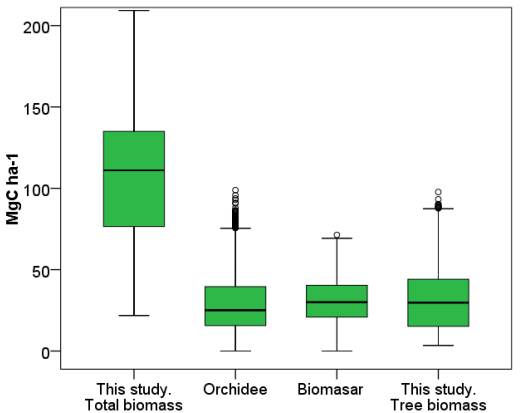

(b)

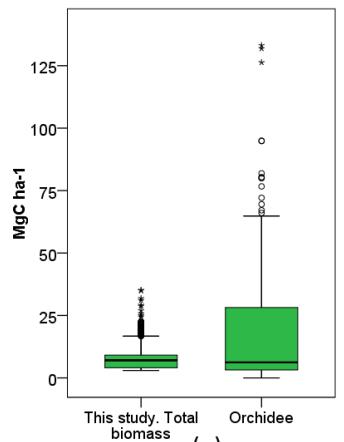

(e)
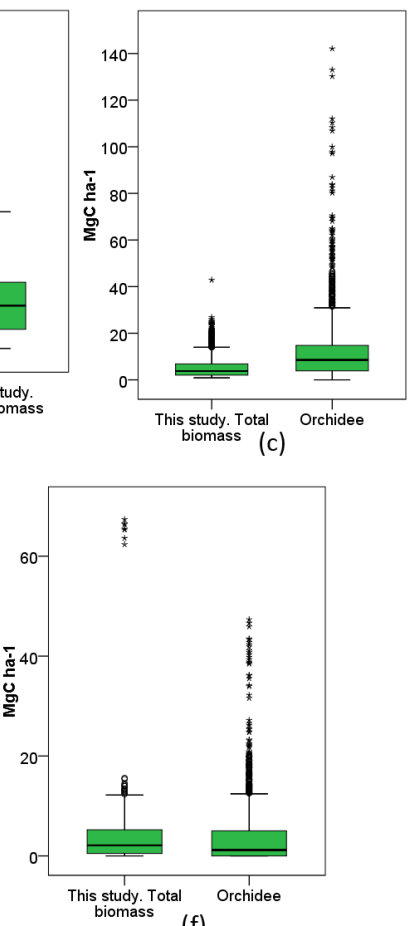

(f)

Figure 7. Box plots of the carbon biomass obtained for each product for the different land covers: (a) tropical forest, (b) boreal forest, (c) crops, (d) temperate forest, (e) savanna and shrub, and (f) grasses.

for studies modeling fire impacts on the climate system as well as fire risk and fire management analysis. While different global land cover maps are available (e.g., Loveland et al., 2000; Bartholomé and Belward, 2005; Bicheron et al., 2008), none of these products can be directly used to determine fire behavior, because they lack the required parameters to run fire behavior models. The fuelbeds, on the other hand, include the necessary information on fuel characteristics to be input in FCCS, and can provide estimations of fuel potentials, biomass, and surface fire behavior.

To generate a global fuel data set product several generalizations and assumptions had to be made, which prevent the comparison of our product with regional more-detailed products. In addition, the uncertainty of each input variable to generate the final database should also be taken into account if using our product for regional-scale studies. A few thoughts on our product limitations and strengths follow.

\subsection{Fuelbed map}

The development of the global fuelbed map includes several improvements compared to the previous product elaborated using this methodology, corresponding to the fuel map of South America (Pettinari et al., 2014). Supplementary information was added to the canopy stratum, which now includes a secondary layer of trees, and also duff information was incorporated, which is particularly relevant in the temperate and boreal biomes of the Northern Hemisphere. This information adds to the total fuel and biomass information, and affects both the behavior outputs and total available carbon biomass. The canopy cover data were also improved. On the one hand, a more recent version of the MODIS VCF was used (collection 5 vs. collection 3), which has a higher accuracy compared to previous versions (Townshend et al., 2011). And on the other hand, the subdivision of the canopy cover into three groups, as well as the creation of sub-fuelbeds according to percentage of canopy cover, allowed obtaining more realistic results than before, because it allowed keeping a higher variability of canopy structure than in the case of using one mean value for the whole fuelbed.

Another improvement for this global map was the use of mean values from several existing fuelbeds or Photo Series, instead of using only one existing value as representative of each of the global fuelbeds. The use of different existing data of the same land cover and biome combination, but from separate locations, provided a better characterization of the diverse ecosystems, generalized by the use of the mean values. With this approach, each global fuelbed represents the mean conditions that could be found in different ecosystems of the same land cover-biome combination.

The disaggregation of the cropland land cover, addressed as the selection of crop species with highest cultivated area per administrative division, also improved the characterization of the crops' fuelbeds compared to the previous product. While the viability of different crops is dependent on 
biophysical parameters (Sacks et al., 2010), it is also affected by socio-economic factors (Rasul and Thapa, 2003; Olesen et al., 2011). Distinct crops have different biomass, react differently to fire, and also the period and conditions in which crops are usually burned are not the same. For example, most of the crops are burned after harvest, to eliminate crop residue and for pest and weed control (Jenkins et al., 1992; McCarty et al., 2009). Sugar cane, on the other hand, is usually burned previous to harvesting, to remove trash, kill pests and facilitate the harvesting process (Cannavam Rípoli et al., 2000); and for this reason the biomass is live, and its amount is high compared to other crops. The inclusion of different crop fuelbeds in different geographic regions of the same land cover-biome combination tackles these issues, and will be able to provide more realistic results when fire behavior or effects are calculated from the fuelbed map.

The FCCS fuelbed database and the Photo Series from which the global fuelbeds were created, while including data from the different existing biomes, reflect the conditions of American ecosystems, and do not have information from other continents. Many studies have shown continental differences within biogeographical regions, including species richness (Barthlott et al., 2007; Kreft and Jetz, 2007), total biomass (Saatchi et al., 2011; Baccini et al., 2012; Banin et al., 2014; Thurner et al., 2014), and fire behavior (Lehmann et al., 2014; Rogers et al., 2015). Some of the most evident differences regarding vegetation behavior to fire were addressed with the inclusion of the regional GlobCover map to account for needle-leaved deciduous trees (Larix) in Asia (fuelbeds with land covers 92, 102, 112 and 122), and with the creation of specific fuelbeds for Australia with Eucalyptus vegetation (land covers 43, 113, 123 and 133). The disaggregation of the crops also tackled this issue. Still, variation of vegetation structure and characteristics within different continents has not been directly addressed, and mean values from global canopy cover and height were used for each fuelbed.

At this point, only the existing FCCS fuelbeds and the Photo Series were used to populate the global fuelbed parameters, because they include all (in the case of the FCCS fuelbeds) or most (in the case of the Photo Series) of the required variables. Many other vegetation databases exist, but they only have information for some of the parameters required. For instance, there are few field databases that include information on dead woody fuels, such as some in the Brazilian Amazon (Cochrane et al., 1999) or in South African and Zambian savannas (Shea et al., 1996). This fuel stratum is critical in determining surface fire behavior, and as such should be included in the information used for the creation of the fuelbeds. But many databases, while having detailed information on tree characteristics, do not specify the dead woody fuels or other surface fuels such as shrubs or grasses (Prasad et al., 2001; Muche et al., 2012). Also, information on litter, lichen, moss, and duff loadings (which affect the total combustible biomass and the fire emissions) is usually published without including detailed data on the rest of the fuels present in the site (Harden et al., 2006). Future improvements of the fuelbed map will involve the inclusion of fuel data from other continents, developing methods to homogenize the information from different sources into fuelbed variables.

The global fuelbed map maintains some of the same limitations as the South American map. Modeling terrestrial ecosystems at a global scale implies the use of a generalized representation of their characteristics (Running and Hunt, 1993). This necessary generalization of the fuelbeds loses much of the complexity of the ecosystems, as mean values of the fuel parameters are assigned globally. Also, only one representative species (or two in the case of mixed forests) was assigned for each vegetation stratum. For this reason, while it is appropriate for global or continental applications, it should be used carefully when working at more detailed scales. Adjustments to the fuelbed parameters should be applied to approximate them to particular regions if possible.

The map also carries the uncertainties and limitations of the original products from which it is based. The GlobCover product, as any other land cover map, includes some misclassification of pixels in certain regions, which has been addressed in their validation report (Bicheron et al., 2008). Also, the Olson biomes' map has sharp boundaries between biomes, while gradual transitions of environmental variables and vegetation cover between adjacent biomes are more realistic (Walker et al., 2003).

\subsection{Carbon biomass}

Even though the objective of our study was not estimating carbon biomass, we considered comparing this output of FCCS with other products as a first assessment of our results. The comparison can be considered successful, as the main spatial trends and actual values of our product agree quite acceptably with existing ones, particularly when considering the differences in methods and scopes between the products that were compared.

Terrestrial biomass is an essential indicator for the monitoring of Earth's ecosystems and climate and for studying biogeochemical cycles, and has promoted the development of many biomass maps in the past few years. We selected diverse products for the comparison of the fuelbeds' biomass, which were generated employing different methods. As a global biomass product, we used the map obtained by the Orchidee DGVM (Yue et al., 2015), because the biomass is calculated separately for different fuel strata, and we were able to select the layers that corresponded to the fuel strata from the fuelbeds, hence obtaining comparable results. Although there is a global biomass product currently available (Ruesch and Gibbs, 2008), it includes data of both living above and below (root) ground biomass. Since the fuelbeds do not include root biomass information, while they do include infor- 
mation on dead ground fuels, the two products were not analogous. We also compared the biomass from the most important forested regions of the world (tropical forests, and Northern Hemisphere temperate and boreal forests) with products developed using remote-sensing technology: Envisat ASAR in the case of the Biomasar product (Santoro et al., 2011), and GLAS in the tropical forest maps (Saatchi et al., 2011; Baccini et al., 2012).

The carbon biomass values for the boreal forests obtained in this study (considering only the tree stratum) were very similar to those obtained for the Biomasar map, with only a $5 \%$ difference in their mean ( 30.9 vs. $32.4 \mathrm{MgCha}^{-1}$ ). Also, both these products and the Orchidee estimations had a similar distribution of the values (see Fig. 7b). On the other hand, when the biomass obtained for all the strata of the fuelbeds was considered, the resulting biomass was much higher. This reflects the significant contribution of the ground fuels to the total carbon pool, as shown in other studies (Yu et al., 2010).

In the case of the temperate forests, our estimations were approximately $30 \%$ higher than the Biomasar biomass. This divergence can be explained by different reasons. First, it should be noted that both products are based on different land cover maps: while the fuelbeds are based on the GlobCover 2005, the land cover map used to determine the forest pixels in Biomasar was the GLC2000 (Bartholomé and Belward, $2005)$, with a different spatial resolution ( $1 \mathrm{~km}$ vs. $\sim 300 \mathrm{~m}$ in our case). Different land cover products generally agree in land cover classification in relatively homogeneous areas, whereas in heterogeneous landscapes or transition zones the disagreement between diverse products can be high (Song et al., 2014). The temperate biome includes some of the widest cropland areas, in many cases intermixed with forest regions or other natural vegetation (García-Feced et al., 2015). These heterogeneous landscapes can be easily classified as forest, mosaic forest with crops or other vegetation, or even other classes, depending on the satellite sensor systems, the classification algorithms, or the diverse legends of the different land cover products. This could cause discrepancies between the two products that are being compared. Simultaneously, as the objective of the biomass assessment was to compare homogeneous land cover areas, only the $0.5^{\circ}$ pixels which had at least $80 \%$ of forest fuelbeds (or mosaics with predominant forest fuelbeds) were included in the analysis, and many European forested areas were excluded. These forests have the highest carbon biomass value in the Biomasar map (Thurner et al., 2014), and their exclusion explains why the values in Table 2 were lower than the ones obtained for this study (49.5 vs. $70.6 \mathrm{MgCha}^{-1}$ ). But if the total Biomasar forest pixels in the temperate biome are analyzed (see Thurner et al. (2014), Table 3), the results show values between 58 and $62 \mathrm{MgCha}^{-1}$, which are more similar to our estimations.

For the tropical forests, the value obtained as the mean biomass from all the pixels with homogeneous forest cover was within the values found for the other three maps, and closest to the Baccini map (110.0 $\mathrm{MgCha}^{-1}$ for our estima- tions versus $109.1 \mathrm{MgCha}^{-1}$ for the Baccini product). The two tropical biomass maps show differences in local biomass values, which have been explored and described by Mitchard et al. (2013, 2014). The results from our analysis showed biomass values for the Baccini higher than for the Saatchi one, which is in line with the results obtained by Mitchard et al. (2013). Even a combined product has been proposed to reduce the discrepancies (Langner et al., 2014). For the purpose of our analysis, we considered the separate products to be both adequate as comparison data. As in the case of the boreal and temperate forests, the biomass from the fuelbeds' map represents a global mean, and does not take into consideration the continental variations. The values of carbon biomass for tropical forests obtained for the Orchidee map were around $30 \%$ higher than the fuelbed map; that could be explained in part because the Orchidee model does not include forest degradation (C. Yue, personal communication, 2015). Another important note should be made regarding the methodology used to obtain the carbon biomass values. Orchidee, as many other DGVMs, relies on the use of plant functional types (PFTs) to parameterize vegetation properties (Poulter et al., 2011). PFTs aggregate multiple species traits according to physiognomy, phenology, photosynthetic pathway, and climate, resulting in a group of small functional classes (Bonan and Levis, 2002). In the case of the Orchidee map, the PFTs were created assigning vegetation proportions from the IGBP DISCover map (Loveland et al., 2000), and the resulting PFTs include classes of woody vegetation (tropical, temperate or boreal; broadleaved or needle-leaved; summergreen, raingreen or evergreen) and grasses and crops (both $\mathrm{C} 3$ and $\mathrm{C} 4$ ). This means that the vegetation characteristics are generalized to a much greater extent than in our fuelbed classification.

The differences between the savanna and shrub biomass results between the Orchidee and the fuelbed maps (15.5 vs. $8.1 \mathrm{MgCha}^{-1}$ ) could be explained both due to the discrepancies between the underlying land cover products, and because the biomass assigned for the woody vegetation in Orchidee does not account for the lower biomass of the shrublands compared to forested areas. These discrepancies are likely aggravated in the case of the croplands. Cultivated areas are one of the most difficult categories to classify in land cover maps, since they can be confused with natural grasslands, and can also be characterized as different kinds of mosaics, depending on the sensor, criteria, threshold, etc., used for the land cover map development (You et al., 2008; Fritz et al., 2015). Discrepancies in cropland classification will produce significant variation in biomass results, especially when comparing crops after harvest with very low biomass (as are most of the fuelbed crop categories) versus other land cover categories such as shrubland or forests.

In all, the carbon biomass obtained for the fuelbeds shows acceptable results compared to the other products analyzed. The results also show consistency between the diverse approaches used to develop the different maps. Future 
work could include further information to the assessment of the biomass results, such as an estimation of soil carbon biomass using data extracted from the Harmonized World Soil Database (FAO/IIASA/ISRIC/ISSCAS/JRC, 2012), as was done by Carvalhais et al. (2014).

Future work will also analyze the continental differences in biomass from other products, in order to improve the spatial distribution of biomass worldwide. This is related to the incorporation of fuel data from different continents, as stated in the previous section.

\subsection{Possible applications of the fuel data set}

The global fuelbed data set developed in this study can be used for different applications, as the FCCS includes a wide set of characteristics of the fuels, and not only the ones required for a particular fuel model. For example, FCCS calculates three fuel potentials (surface fire behavior potential, crown fire potential, and available fuel potential) using benchmark environmental variables, which can be used to evaluate fire danger based solely on fuel characteristics (Sandberg et al., 2007; Prichard et al., 2013). Also, specific environmental variables (fuel moisture, slope, and wind speed) can be assigned to calculate expected surface fire behavior for different weather conditions, as it provides results on rate of spread, flame length, and reaction intensity. Furthermore, the available fuel and carbon results obtained for each fuelbed can be used to calculate fuel consumption and pollutant emissions using tools such as Consume (Prichard et al., 2005).

All these results provide information for different applications. The fuelbed map could be used for global or continental fire danger assessment, using the values of fire potentials or fire behavior to complement existing early warning systems, such as EFFIS (http://forest.jrc.ec.europa.eu/ effis/) (San Miguel-Ayanz et al., 2012) or the Global Wildland Fire Early Warning System (GWFEWS, http://www. fire.uni-freiburg.de/gwfews/; de Groot et al., 2006). For those countries lacking information on fuel types, it may enhance current fire danger systems that are based solely on weather information.

Finally, our product could also be used to calculate emissions from wildland fires at country or continental scale from Consume or other fire emission models, complementing information supplied by other products as the Global Fire Emissions Database (GFED, http://www.globalfiredata.org/, last access: September 2015).

Due to the resolution of the map and the global characteristics of the fuelbeds, all of these applications are intended for regional to global studies and are not intended for the local scale. For example, this map is not intended to predict "real-world" fire behavior at a local scale, which would need a much finer spatial resolution of the fuelbeds and equally detailed weather information. For this purpose, other systems such as FlamMap (Finney, 2006) or FARSITE (Finney, 2004) would be a more appropriate option.

To obtain a more detailed fuelbed map for a local region (such as a country or province) we would suggest to use the methodology described in this article to create a custom fuelbed map, using local vegetation information if possible. If no local information is available, it would be possible to create a data set with the same data sources used in this article, but assigning mean information on canopy cover, height, and fuelbed parameters related only to the study area, thus describing better the local conditions.

Future research will focus on the application of this fuelbed data set to different fire management issues, particularly obtaining fire behavior and potential values for fire danger estimation.

\section{Conclusions}

This study developed the first global fuel data set for modeling wildland fire danger and fire effects. The data set is based on the Fuel Characteristic Classification System (FCCS), and includes parameters that may be used to obtain quantitative estimations of fire behavior variables. The geographical distribution of the fuelbeds was created by combining the GlobCover 2005 V2.2 land cover map and the Olson biomes' map, with the aid of some ancillary information for particular land cover types or regions. A total of 274 fuelbeds were created (359 if the sub-fuelbeds are considered). Each fuelbed was assigned a set of parameters related to fire behavior, extracted from global or regional databases. With these parameters, FCCS can be run to obtain fire potentials, surface fire behavior, and carbon biomass for each fuelbed.

A comparison between the carbon biomass obtained for our fuelbeds and four other regional or global biomass products showed reasonable agreement both in terms of geographical distribution and biomass load. The highest Spearman's rho coefficients were found for tropical and boreal forests ( $\rho_{\mathrm{s}}=0.79$ and 0.77 , respectively), with moderate results for the remaining land covers analyzed (coefficients between 0.20 and 0.66 ). This fuel map could be used for a varied range of applications, including fire danger assessment, fuel consumption calculations or emissions inventory.

\section{Data availability}

The resulting global fuelbed map in GeoTIFF format, as well as a spreadsheet containing all the variables assigned to each fuelbed and the sources of the information used for their creation, is available from Pettinari (2015), https: //doi.pangaea.de/10.1594/PANGAEA.849808.

Acknowledgements. The authors thank Susan Prichard, Paige Eagle, Anne Andreu, and Roger Ottmar for their help in the use of 
FCCS, and Ernesto Alvarado and Nancy French for providing the information on the Mexican and agricultural fuelbeds, respectively.

We would also like to thank Chao Yue and Martin Thurner for supplying their biomass data sets and for their useful comments regarding the carbon biomass results, and Edward Mitchard and Alessandro Baccini for providing the tropical biomass data sets.

Finally, we would like to thank the anonymous authors and the editor of the article for their suggestions, which helped us improve the document.

Edited by: K. Thonicke

\section{References}

Agee, J. K., Wakimoto, R. H., Darley, E. F., and Biswell, H. H.: Eucalyptus fuel dynamics, and fire hazard in the Oakland Hills, Calif. Agr., 27, 13-15, 1973.

Alonso-Canas, I. and Chuvieco, E.: Global burned area mapping from ENVISAT-MERIS and MODIS active fire data, Remote Sens. Environ., 163, 140-152, doi:10.1016/j.rse.2015.03.011, 2015.

Anderson, H. E.: Aids to Determining Fuel Models for Estimating Fire Behavior, USDA Forest Service, Intermountain Forest and Range Experiment Station, Odgen, UT, General Technical Report INT-122, 26 pp., 1982.

Baccini, A., Goetz, S. J., Walker, W. S., Laporte, N. T., Sun, M., Sulla-Menashe, D., Hackler, J., Beck, P. S. A., Dubayah, R., Friedl, M. A., Samanta, S., and Houghton, R. A.: Estimated carbon dioxide emissions from tropical deforestation improved by carbon-density maps, Nature Climate Change, 2, 182-185, doi:10.1038/nclimate1354, 2012.

Banin, L., Lewis, S. L., Lopez-Gonzalez, G., Baker, T. R., Quesada, C. A., Chao, K.-J., Burslem, D. F. R. P., Nilus, R., Abu Salim, K., Keeling, H. C., Tan, S., Davies, S. J., Monteagudo Mendoza, A., Vasquez, R., Lloyd, J., Neill, D. A., Pitman, N., and Phillips, O. L.: Tropical forest wood production: a cross-continental comparison, J. Ecol., 102, 1025-1037, doi:10.1111/1365-2745.12263, 2014.

Barthlott, W., Hostert, A., Kier, G., Küper, W., Kreft, H., Mutke, J., Rafiqpoor, M. D., and Sommer, J. H.: Geographic patterns of vascular plant diversity at continental to global scales, Erdkunde, 61, 305-316, 2007.

Bartholomé, E. and Belward, A. S.: GLC2000: a new approach to global land cover mapping from Earth observation data, Int. J. Remote Sens., 26, 1959-1977, doi:10.1080/01431160412331291297, 2005.

Bicheron, P., Defourny, P., Brockmann, C., Schouten, L., Vancutsem, C., Huc, M., Bontemps, S., Leroy, M., Achard, F., Herold, M., Ranera, F., and Arino, O.: GLOBCOVER: Products description and validation report, MEDIAS-France/POSTEL, Toulouse, France, 47 pp., 2008.

Bonan, G. B. and Levis, S.: Landscapes as patches of plant functional types: An integrating concept for climate and ecosystem models, Global Biogeochem. Cy., 16, 5-1-5-23, doi:10.1029/2000GB001360, 2002.

Cannavam Rípoli, T. C., Molina Jr., W. F., and Cunali Rípoli, M. L.: Energy potential of sugar cane biomass in Brazil, Sci. Agr., 57, 677-681, 2000.
Carroll, M., Townshend, J., Hansen, M., DiMiceli, C., Sohlberg, R., and Wurster, K.: MODIS Vegetative Cover Conversion and Vegetation Continuous Field, in: Land Remote Sensing and Global Environmental Change, edited by: Ramachandran, B., Justice, C. O., and Abrams, M. J., Remote Sensing and Digital Image Processing, Springer New York, 11, 725-745, 2011.

Carvalhais, N., Forkel, M., Khomik, M., Bellarby, J., Jung, M., Migliavacca, M., Mu, M., Saatchi, S., Santoro, M., Thurner, M., Weber, U., Ahrens, B., Beer, C., Cescatti, A., Randerson, J. T., and Reichstein, M.: Global covariation of carbon turnover times with climate in terrestrial ecosystems, Nature, 514, 213-217, doi:10.1038/nature13731, 2014.

Chuvieco, E., Aguado, I., Jurdao, S., Pettinari, M. L., Yebra, M., Salas, J., Hantson, S., de la Riva, J., Ibarra, P., Rodrigues, M., Echeverría, M. T., Azqueta, D., Román, M. V., Bastarrika, A., Martínez, S., Recondo, C., Zapico, E., and Martínez-Vega, F. J.: Integrating geospatial information into fire risk assessment, Int. J. Wildland Fire, 23, 606-619, doi:10.1071/WF12052, 2014.

Cochrane, M. A., Alencar, A., Schulze, M. D., Souza Jr., C. M., Nepstad, D. C., Lefebvre, P., and Davidson, E. A.: Positive feedbacks in the fire dynamic of closed canopy tropical forests, Science, 284, 1832-1835, 1999.

Cohen, J. D. and Deeming, J. E.: The National Fire-Danger Rating System: basic equations, USDA Forest Service, Pacific Southwest Forest and Range Experiment Station, Berkeley, CA, General Technical Report PSW-82, 23 pp., 1985.

de Groot, W. J., Goldammer, J. G., Keenan, T., Brady, M. A., Lynham, T. J., Justice, C. O., Csiszar, I. A., and O'Loughlin, K.: Developing a global early warning system for wildland fire, V International Conference on Forest Fire Research, Coimbra, Portugal, 12 pp., 2006.

Department of the Environment and Water Resources: Australia's Native Vegetation - A summary of Australia's Major Vegetation Groups, edited by: Department of the Environment and Water Resources, Australian Government, Canberra, 44 pp., 2007.

Di Gregorio, A.: Land Cover Classification System. Classification concepts and user manual, Software version 2, Environment and Natural Resources Series, FAO, Rome, 208 pp., 2005.

DiMiceli, C. M., Carroll, M. L., Sohlberg, R. A., Huang, C., Hansen, M. C., and Townsend, J. R. G.: Vegetation Continuous Field (MOD44B), Collection 5 Percent Tree Cover, University of Maryland, College Park, Maryland, 2011.

Dymond, C. C., Roswintiarti, O., and Brady, M.: Characterizing and mapping fuels for Malaysia and western Indonesia, Int. J. Wildland Fire, 13, 323-334, 2004.

FAO/IIASA/ISRIC/ISSCAS/JRC: Harmonized World Soil Database (version 1.2), FAO, Rome, Italy and IIASA, Laxenburg, Austria, 2012.

Finney, M. A.: FARSITE: Fire Area Simulator - Model development and evaluation, USDA Forest Service, Rocky Mountain Research Station, RMRS-RP-4 Revised, 52 pp., 2004.

Finney, M. A.: An Overview of FlamMap Fire Modeling Capabilities, in: Fuels Management-How to Measure Success, edited by: Andrews, P. L. and Butler, B. W., Conference Proceedings, 2830 March 2006, Portland, OR, Proceedings RMRS-P-41, Fort Collins, CO, U.S. Department of Agriculture, Forest Service, Rocky Mountain Research Station, 213-220, 2006.

Finney, M. A., McHugh, C. W., Grenfell, I. C., Riley, K. L., and Short, K. C.: A simulation of probabilistic wildfire riks compo- 
nents for the continental United States, Stoch. Env. Res Risk A., 25, 973-1000, doi:10.1007/s00477-011-0462-z, 2011.

French, N. H. F., McKenzie, D., Ottmar, R. D., McCarty, J. L., Norheim, R. A., Hamermesh, N., and Soja, A. J.: A US national fuels database and map for calculating carbon emissions from wildland and prescribed fire, 4th Fire Behavior and Fuels Conference, 1-4 July 2013, St. Petersburg, Russia, 8 pp., 2013.

Fritz, S., See, L., McCallum, I., et al.: Mapping global cropland and field size, Glob. Change Biol., 21, 1980-1992, doi:10.1111/gcb.12838, 2015.

García-Feced, C., Weissteiner, C. J., Baraldi, A., Paracchini, M. L., Maes, J., Zulian, G., Kempen, M., Elbersen, B., and Pérez-Soba, M.: Semi-natural vegetation in agricultural land: European map and links to ecosystem service supply, Agron. Sustain. Dev., 35, 273-283, doi:10.1007/s13593-014-0238-1, 2015.

Giglio, L., Randerson, J. T., and van der Werf, G. R.: Analysis of daily, monthly, and annual burned area using the fourthgeneration global fire emissions database (GFED4), J. Geophys Res.-Biogeo., 118, 317-328, doi:10.1002/jgrg.20042, 2013.

Harden, J. W., Manies, K. L., Turetsky, M. R., and Neff, J. C.: Effects of wildfire and permafrost on soil organic matter and soil climate in interior Alaska, Glob. Change Biol., 12, 2391-2403, doi:10.1111/j.1365-2486.2006.01255.x, 2006.

Jenkins, B. M., Turn, S. Q., and Williams, R. B.: Atmospheric emissions from agricultural burning in California: determination of burn fractions, distribution factors, and crop-specific contributions, Agr. Ecosyst. Environ., 38, 313-330, 1992.

Keane, R. E., Burgan, R. E., and van Wagtendonk, J.: Mapping wildland fuels for fire management across multiple scales: Integrating remote sensing, GIS, and biophysical modeling, Int. J. Wildland Fire, 10, 301-319, 2001.

Kesselmeier, J. and Staudt, M.: Biogenic volatile organic compounds (VOC): an overview on emission, physiology and ecology, J. Atmos. Chem., 33, 23-88, 1999.

Kreft, H. and Jetz, W.: Global patterns and determinants of vascular plant diversity, P. Natl. Acad. Sci. USA, 104, 5925-5930, 2007.

Krinner, G., Viovy, N., de Noblet-Ducoudré, N., Ogée, J., Polcher, J., Friedlingstein, P., Ciais, P., Sitch, S., and Prentice, I. C.: A dynamic global vegetation model for studies of the coupled atmosphere-biosphere system, Global Biogeochem. Cy., 19, GB1015, doi:10.1029/2003GB002199, 2005.

Langner, A., Achard, F., and Grassi, G.: Can recent pan-tropical biomass maps be used to derive alternative Tier 1 values for reporting REDD+ activities under UNFCCC?, Environ. Res. Lett., 9, 124008, doi:10.1088/1748-9326/9/12/124008, 2014.

Lehmann, C. E. R., Anderson, M. T., Sankaran, M., Higgins, S. I., Archibald, S., Hoffman, W. A., Hanan, N. P., Williams, R. J., Fensham, R. J., Felfili, J., Hutley, L. B., Ratnam, J., San Jose, J., Montes, R., Franklin, D., Russell-Smith, J., Ryan, C. M., Durigan, G., Hiernaux, P., Haidar, R., Bowman, D. M. J. S., and Bond, W. J.: Savanna vegetation-fire-climate relationships differ among continents, Science, 343, 548-552, doi:10.1126/science.1247355, 2014.

Loveland, T. R., Reed, B. C., Brown, J. F., Ohlen, D. O., Zhu, Z., Yang, L., and Merchant, J. W.: Development of a global land cover characteristics database and IGBP DISCover from $1 \mathrm{~km}$ AVHRR data, Int. J. Remote Sens., 21, 1303-1330, 2000.

McCarty, J. L., Korontzi, S., Justice, C. O., and Loboda, T.: The spatial and temporal distribution of crop residue burning in the continental United States, Sci. Total Environ., 407, 5701-5712, doi:10.1016/j.scitotenv.2009.07.009, 2009.

McKenzie, D., Raymond, C. L., Kellogg, L.-K. B., Norheim, R. A., Andreu, A. G., Bayard, A. C., Kopper, K. E., and Elman, E.: Mapping fuels at multiple scales: landscape applications of the Fuel Characteristic Classification System, Can. J. Forest Res., 37, 2421-2437, doi:10.1139/X07-056, 2007.

Mitchard, E. T. A., Saatchi, S. S., Baccini, A., Asner, G. P., Goetz, S. J., Harris, N. L., and Brown, S.: Uncertainty in the spatial distribution of tropical forest biomass: a comparison of pantropical maps, Carbon Balance and Management, 8, 13 pp., doi:10.1186/1750-0680-8-10, 2013.

Mitchard, E. T. A., Feldpausch, T. R., Brienen, R. J. W., et al.: Markedly divergent estimates of Amazon forest carbon density from ground plots and satellites, Global Ecol. Biogeogr., 23, 935-946, doi:10.1111/geb.12168, 2014.

Monfreda, C., Ramankutty, N., and Foley, J. A.: Farming the planet: 2. Geographic distribution of crop areas, yields, physiological types, and net primary production in the year 2000, Global Biogeochem. Cy., 22, GB1022, doi:10.1029/2007GB002947, 2008.

Morfín-Ríos, J. E., Alvarado-Celestino, E., Jardel-Peláez, E. J., Vihnanek, R. E., Wright, D. K., Michel-Fuentes, J. M., Wright, C. S., Ottmar, R. D., Sandberg, D. V., and Nájera-Díaz, A.: Photo series for quantifying forest fuels in Mexico: montane subtropical forests of the Sierra Madre del Sur and temperate forests and montane shrubland of the northern Sierra Madre Oriental., University of Washington, College of Forest Resources, Seattle, Pacific Wildland Fire Sciences Laboratory Special Pub. No. 1, 93 pp., 2008.

Muche, G., Schmiedel, U., and Jürgens, N.: BIOTA Southern Africa Biodiversity Observatories Vegetation Database, Biodiversity \& Ecology, 4, 111-123, doi:10.7809/b-e.00066, 2012.

Nadeau, L. B., McRae, D. J., and Jin, J.-Z.: Development of a National Fuel-type Map for Canada Using Fuzzy Logic, Canadian Forest Service, Edmonton, Information Report NOR-X-406, 26 pp., 2005.

Olesen, J. E., Trnka, M., Kersebaum, K. C., Skjelvag, A. O., Seguin, B., Peltonen-Sainio, P., Rossi, F., Kozyra, J., and Micale, F.: Impacts and adaptation of European crop production systems to climate change, Eur. J. Agron., 34, 96-112, 2011.

Olson, D. M., Dinerstein, E., Wikramanayake, E. D., Burgess, N. D., Powell, G. V. N., Underwood, E. C., D’Amico, J. A., Itoua, I., Strand, H. E., Morrison, J. C., Loucks, C. J., Allnutt, T. F., Ricketts, T. H., Kura, Y., Lamoreux, J. F., Wettengel, W. W., Hedao, P., and Kassem, K. R.: Terrestrial Ecoregions of the World: A New Map of Life on Earth, BioScience, 51, 933938, 2001.

Ottmar, R. D., Vihnanek, R. E., Miranda, H. S., Sato, M. N., and Andrade, S. M. A.: Stereo Photo Series for quantifying cerrado fuels in Central Brazil - Volume I, USDA Forest Service, Pacific Northwest Research Station, Seattle, General Technical Report PNW-GTR-519, 88 pp., 2001.

Ottmar, R. D., Sandberg, D. V., Riccardi, C. L., and Prichard, S. J.: An overview of the Fuel Characteristic Classification System Quantifying, classifying, and creating fuelbeds for resource planning, Can. J. Forest Res., 37, 2383-2393, 2007.

Pausas, J. G. and Keeley, J. E.: A burning story: the role of fire in the history of life, BioScience, 59, 593-601, doi:10.1525/bio.2009.59.7.10, 2009. 
Pettinari, M. L.: Global Fuelbed Dataset, Alcala de Henares, doi:10.1594/PANGAEA.849808, 2015.

Pettinari, M. L., Ottmar, R. D., Prichard, S. J., Andreu, A. G., and Chuvieco, E.: Development and mapping of fuel characteristics and associated fire potentials for South America, Int. J. Wildland Fire, 23, 643-654, doi:10.1071/WF12137, 2014.

Poulter, B., Ciais, P., Hodson, E., Lischke, H., Maignan, F., Plummer, S., and Zimmermann, N. E.: Plant functional type mapping for earth system models, Geosci. Model Dev., 4, 993-1010, doi:10.5194/gmd-4-993-2011, 2011.

Prasad, V. K., Kant, Y., Gupta, P. K., Sharma, C., Mitra, A. P., and Badarinath, K. V. S.: Biomass and combustion characteristics of secondary mixed deciduous forests in Eastern Ghats of India, Atmos. Environ., 35, 3085-3095, 2001.

Prichard, S. J., Ottmar, R. D., and Anderson, G. K.: Consume 3.0 User's Guide, USDA Forest Service, Pacific Northwest Research Station, Seattle, WA, 239 pp., 2005.

Prichard, S. J., Sandberg, D. V., Ottmar, R. D., Eberhardt, E., Andreu, A., Eagle, P., and Swedin, K.: Fuel Characteristic Classification System Version 3.0: Technical Documentation, USDA Forest Service, Pacific Norhtwest Research Station, Portland, OR, PNW-GTR-887, 88 pp., 2013.

PROMETHEUS S.V. Project: Management techniques for optimization of suppression and minimization of wildfire effects, System validation, edited by: European Comission, Contract Number ENV4-CT98-0716, 1999.

Rasul, G. and Thapa, G. B.: Shifting cultivation in the mountains of South and Southeast Asia: regional patterns and factors influencing the change, Land Degrad. Dev., 14, 495-508, doi:10.1002/ldr.570, 2003.

Riaño, D., Chuvieco, E., Salas, J., Palacios-Orueta, A., and Bastarrika, A.: Generation of fuel type maps from Landsat TM images and ancillary data in Mediterranean ecosystems, Can. J. Forest Res., 32, 1301-1315, 2002.

Riaño, D., Chuvieco, E., Condés, S., González-Matesanz, J., and Ustin, S. L.: Generation of crown bulk density for Pinus sylvestris L. from lidar, Remote Sens. Environ., 92, 345-352, doi:10.1016/j.rse.2003.12.014, 2004.

Riccardi, C. L., Ottmar, R. D., Sandberg, D. V., Andreu, A., Elman, E., Kopper, K., and Long, J.: The fuelbed: a key element of the Fuel Characteristic Classification System, Can. J. Forest Res., 37, 2394-2412, doi:10.1139/x07-143, 2007.

Rogers, B. M., Soja, A. J., Goulden, M. L., and Randerson, J. T.: Influence of tree species on continental differences in boreal fires and climate feedback, Nat. Geosci., 8, 228-234, doi:10.1038/ngeo2352, 2015

Rollins, M. G.: LANDFIRE: a nationally consistent vegetation, wildland fire, and fuel assessment, Int. J. Wildland Fire, 18, 235249, 2009.

Rollins, M. G., Keane, R. E., and Parsons, R. A.: Mapping fuels and fire regimes using remote sensing, ecosystem simulation, and gradient modeling, Ecol. Appl., 1, 75-95, 2004.

Rothermel, R. C.: A mathematical model for predicting fire spread in wildland fuels, USDA Forest Service, Intermountain Forest and Range Experiment Station, Odgen, UT, Research Paper INT115, 40 pp., 1972.

Rothermel, R. C.: How to predict the spread and intensity of forest and range fires, National Wildfire Coordinating Group, USDA
Forest Service Intermountain Research Station, Boise, ID, INT143, 166 pp., 1983.

Ruesch, A. and Gibbs, H. K.: New IPCC Tier-1 global biomass carbon map for the year 2000, Oak Ridge National Laboratory, Oak Ridge, Tennessee, 2008.

Running, S. W. and Hunt, R. J.: Generalization of a forest ecosystem process model for other biomes, BIOME-BGC, and an application for global-scale models, in: Scaling physiological processes. Leaf to globe, edited by: Roy, J., Ehleringer, J. R., and Field, C. B., Academic Press, Inc., San Diego, 141-158, 1993.

Saatchi, S. S., Harris, N. L., Brown, S., Lefsky, M. A., Mitchard, E. T. A., Salas, W., Zutta, B. R., Buermann, W., Lewis, S. L., Hagen, S., Petrova, S., White, L., Silman, M., and Morel, A.: Benchmark map of forest carbon stocks in tropical regions across three continents, P. Natl. Acad. Sci. USA, 108, 9899-9904, doi:10.1073/pnas.1019576108, 2011.

Sacks, W. J., Deryng, D., Foley, J. A., and Ramankutty, N.: Crop planting dates: an analysis of global patterns, Global Ecol. Biogeogr., 19, 607-620, doi:10.1111/j.1466-8238.2010.00551.x, 2010.

San Miguel-Ayanz, J., Schulte, E., Schmuck, G., Camia, A., Strobl, P., Liberta, G., Giovando, C., Boca, R., Sedano, F., Kempeneers, P., McInerney, D., Withmore, C., Santos de Oliveira, S., Rodrigues, M., Durrant, T., Corti, P., Oehler, F., Vilar, L., and Amatulli, G.: Comprehensive Monitoring of Wildfires in Europe: The European Forest Fire Information System (EFFIS), in: Approaches to Managing Disaster - Assessing Hazards, Emergencies and Disaster Impacts, edited by: Tiefenbacher, J., InTech, 87-108, 2012.

Sandberg, D. V., Riccardi, C. L., and Schaaf, M. D.: Fire potential rating for wildland fuelbeds using the Fuel Characteristic Classification System, Can. J. Forest Res., 37, 2456-2463, doi:10.1139/x07-093, 2007.

Santoro, M., Beer, C., Cartus, O., Schmullius, C., Shvidenko, A., McCallum, I., Wegmüller, U., and Weismann, A.: Retrieval of growing stock volume in boreal forest using hyper-temporal series of Envisat ASAR ScanSAR backscatter measurements, Remote Sens. Environ., 115, 490-507, 2011.

Schultz, M. G., Heil, A., Hoelzemann, J. J., Spessa, A., Thonicke, K., Goldammer, J. G., Held, A. C., Pereira, J. M. C., and van het Bolscher, M.: Global wildland fire emissions from 1960 to 2000, Global Biogeochem. Cy., 22, GB2002, doi:10.1029/2007GB003031, 2008.

Scott, J. H. and Burgan, R. E.: Standard fire behavior fuel models: a comprehensive set for use with Rothermel's Surface Fire Spread Model, USDA Forest Service, Rocky Mountain Research Station, Fort Collins, CO, RMRS-GTR-153, 80 pp., 2005.

Sebastián-Lopez, A., San Miguel-Ayanz, J., and Libertá, G.: An integrated forest fire risk index for Europe, in: A decade of transeuropean remote sensing cooperation, edited by: Buchroithner, M. F., Balkema, Rotterdam, 83-88, 2001.

Shea, R. W., Shea, B. W., Kauffman, J. B., Ward, D. E., Haskins, C. I., and Scholes, M. C.: Fuel biomass and combustion factors associated with fires in savanna ecosystems of South Africa and Zambia, J. Geophys. Res., 101, 23551-23568, 1996.

Simard, M., Pinto, N., Fisher, J. B., and Baccini, A.: Mapping forest canopy height globally with spaceborne lidar, J. Geophys. Res., 116, G04021, doi:10.1029/2011JG001708, 2011. 
Song, X.-P., Huang, C., Feng, M., Sexton, J. O., Channan, S., and Townsend, J. R.: Integrating global land cover products for improved forest cover characterization: an application in North America, International Journal of Digital Earth, 7, 709-724, doi:10.1080/17538947.2013.856959, 2014.

Stocks, B. J., Lawson, B. D., Alexander, M. E., Van Wagner, C. E., McAlpine, R. S., Lynham, T. J., and Dubé, D. E.: Canadian Forest Fire Danger Rating System: an overview, Forestry Chron., 65, 258-265, 1989.

Thurner, M., Beer, C., Santoro, M., Carvalhais, N., Wutzler, T., Schepaschenko, D., Shvidenko, A., Kompter, E., Ahrens, B., Levick, S. R., and Schmullius, C.: Carbon stock and density of northern boreal temperate forests, Global Ecol. Biogeogr., 23, 297-310, doi:10.1111/geb.12125, 2014.

Townshend, J., Hansen, M., Carroll, M., DiMiceli, C., Sohlberg, R., and Huang, C.: User Guide for the MODIS Vegetation Continuous Fields product Collection 5 version 1, University of Maryland, Maryland, 12 pp., 2011.
Walker, S., Wilson, J. B., Steel, J. B., Rapson, G. L., Smith, B., King, W. M., and Cottam, Y. H.: Properties of ecotones: Evidence from five ecotones objectively determined from a coastal vegetation gradient, J. Veg. Sci., 14, 579-590, doi:10.1111/j.16541103.2003.tb02185.x, 2003.

You, L., Wood, S., and Sebastian, K.: Comparing and synthesizing different global agricultural land datasets for crop allocation modeling, XXIst ISPRS Congress Technical Comission VII, Beijing, China, 1433-1440, 2008.

Yu, Z., Loisel, J., Brosseau, D. P., Beilman, D. W., and Hunt, S. J.: Global peatland dynamics since the Last Glacier Maximum, Geophys. Res. Lett., 37, L13402, doi:10.1029/2010GL043584, 2010.

Yue, C., Ciais, P., Cadule, P., Thonicke, K., and van Leeuwen, T. T.: Modelling the role of fires in the terrestrial carbon balance by incorporating SPITFIRE into the global vegetation model ORCHIDEE - Part 2: Carbon emissions and the role of fires in the global carbon balance, Geosci. Model Dev., 8, 1321-1338, doi:10.5194/gmd-8-1321-2015, 2015. 